\title{
BIOAKTIVITAS EKSTRAK METANOL DAN FRAKSI N-HEKSANA DAUN SUNGKAI (PERONEMA CANESCENS JACK) TERHADAP LARVA UDANG (ARTEMIA SALINA LEACH)
}

\author{
Islamudin Ahmad dan Arsyik Ibrahim \\ Laboratorium Penelitian dan Pengembangan FARMAKA TROPIS Fakultas Farmasi \\ Universitas Mulawarman, Samarinda, Kalimantan Timur \\ email: islamudinahmad@farmasi.unmul.ac.id
}

\begin{abstract}
ABSTRAK
Penelitian bioaktivitas ekstrak methanol dan farksi $n$-heksana daun sungkai (Peronema canesens JACK) dengan metode brine shrimp lethality test (BSLT) telah dilakukan pengujiannya. Penelitian ini bertujuan untuk mengetahui rendemen ekstrak, dan bagaimana bioaktivitasnya terhadap Artemia salina Leach. Penelitian ini menggunakan metode brine shrimp lethality test dimana data penelitiannya diperoleh dengan mengamati jumlah hewan uji yang mati, kemudian data tersebut diolah dengan menggunakan tabel Reed and Muench. Hasil pengujian ekstrak daun sungkai dengan metode brine shrimp lethality test bersifat bioaktif terhadap larva Artemia salina Leach. Dengan nilai $\mathrm{LC}_{50}$. dari ekstrak methanol adalah 387,257 ppm dan n-heksana adalah 107,399 ppm.
\end{abstract}

Kata Kunci: Peronema canesens Jack, Artemia salina Leach, BSLT

\section{PENDAHULUAN}

Indonesia adalah negara dengan hutan tropis paling besar ketiga di dunia (setelah Brazil dan Zaire). Keanekaragaman hayati merupakan basis berbagai pengobatan dan penemuan industri farmasi dimasa mendatang. Jumlah tumbuhan berkhasiat obat di Indonesia diperkirakan sekitar 1.260 jenis tumbuhan. Salah satunya tanaman sungkai (Peronema canescens Jack) adalah salah satu obat herbal yang terdapat di Indonesia. Secara empiris, daun sungkai dimanfaatkan oleh masyarakat sebagian masyarakat untuk sakit gigi dan penurun demam (Heyne, 1987) Selain itu, daun sungkai juga dimanfaatkan untuk mengobati malaria (Fatriyadi, 2008). Dan tanaman bagian daun Sungkai mengandung metabolit sekunder seperti alkaloid, flavonoid, dan tannin (Hadi, 2011).

Kecenderungan gaya hidup back to neturalsekarang ini membuat pengobatan herbal semakin meningkat pemakaiannya, ditunjang lagi dengan banyaknya kalangan medis yang ikut serta dalam mengembangkannya. Kecenderungan ini didasari oleh beberapa alasan, diantaranyan harga obat-obatan modem yang semakin mahal menyebabkan masyarakat mulai cari altenatif pengobatan yang murah dan mudah didapatkan, serta tidak kalah manjur.

Belum banyak penelitian yang dilakukan terhadap daun sungkai, karena penelitian daun ini sebagai bahan obat di lingkungan masyarakat masih kurang, maka perlu dilakukan pengujian dasar untuk menentukan bioaktivitas dari tumbuhan ini. Salah satu cara untuk menguji bioaktivitas ekstrak tumbuhan yaitu dengan metode BSLT (Brine Shrimp Lethality Test). Bioaktivitas adalah suatu kemampuan suatu senyawa aktif yang terkandung dalam tumbuhan yang dapat memberikan pengaruh terhadap organisme tertentu.

Metode BSLT merupakan salah satu metode yang digunakan untuk penapisan awal senyawa-senyawa yang diduga memiliki senyawa aktif. Penelitian ini menggunakan Artemia 
salina Leach sebagai hewan uji. Parameter yang digunakan untuk menunjukkan adanya aktivitas biologi suatu senyawa yaitu jumlah kematian Artemia salina Leach. Metode ini dilakukan dengan menentukan besarnya $\mathrm{LC}_{50}$ selama 24 jam. Suatu ekstrak tanaman atau fraksi ekstrak tanaman yang mempunyai $\mathrm{LC}_{50}$ kurang dari 1000 ppm dapat diduga memiliki aktivitas seperti sitotoksik, anti mikroba, dan pestisida (Colegate and Molyneux, 1993).

Berdasarkan hal tersebut dilakukan penelitian Uji bioaktivitas ekstrak daun sungkai menggunakan metode BSLT. Penelitian ini merupakan penelitian pendahuluan untuk mengetahui bioaktivitas ekstrak daun sungkai untuk pemanfaatannya sebagai sitotoksik, anti mikroba, dan pestisida.

\section{METODE PENELITIAN}

\section{Peralatan Penelitian}

Alat yang digunakan di dalam penelitian ini adalah Topels, wadah kaca tempat penetasan telur udang, Corong pisah,rotary evaporator (Eyela), timbangan digital, labu Erlenmeyer (Pyrex), gelas ukur (Pyrex), keranjang, botol vial, gelas kimia (Pyrex), desikator dan peralatan kaca lainnya yang mendukung.

\section{Sampel penelitian}

Bahan yang ingin diteliti adalah tanaman sungkai (Peronema canescens Jack). Bagian yang ingin diteliti pada tanaman ini adalah bagian daunnya. Tumbuhan yang diambil merupakan tanaman liar yang tidak diketahui usianya. Tanaman ini diperoleh di Poros Samarinda menuju Balikpapan.

\section{Bahan Penelitian}

Bahan yang digunakan dalam penelitian ini adalah Daun Sungkai (Peronema canesens Jack) metanol, nheksan, aquades, tween 80,aluminium
voil,Artemia salina Leach, air laut, ragi dan kertas saring.

\section{Prosedur Penelitian}

\section{Ekstraksi}

\begin{tabular}{lcr} 
Daun & \multicolumn{1}{c}{ Sungkaisegar yang } \\
digunakan & dalam penelitian ini \\
diidentifikasi & terlebih dahulu di \\
Laboratorium & Dendrologi dan Ekologi
\end{tabular} Hutan, Fakultas Kehutanan, Universitas Mulawarman, Samarinda. Daun Sungkai yang digunakan sebelumnya ditimbang terlebih dahulu dan didapatkan berat daun sungkai sebelum dan sesudah dikeringkan 2370 g dan 586 g. Daun Sungkai dikeringkan dengan cara diangin-anginkan tanpa terkena sinar matahari langsung. Kemudian dilakukan maserasi atau perendaman dengan pelarut metanol dalam wadah kaca. Setelah proses ekstraksi selesai ,larutan ekstrak diuapkan pelarutnya dengan menggunakan alatrotary evaporator. Sisa pelarut diuapkan dengan menggunakanwaterbath sampai didapatkan ekstrak yang kering.

\section{Fraksinasi}

Ekstrak yang didapatkan kemudian difraksinasi dengan metode fraksinasi cair-cairmenggunakan pelarut n-heksana.

\section{Perhitungan Rendemen}

Penentuan rendemen daun Sungkai diperoleh dengan cara membagi berat akhir ekstrak daun Sungkai yang diperoleh dari proses ekstraksi dan fraksinasi dengan berat awal

\section{Penentuan Konsentrasi}

Konsentrasi ekstrak kasar metanol dan fraksi n-heksanan daun sungkai yang digunakan pada perlakuan adalah konsentrasi tersebut ditetapkan berdasarkan hasil uji pendahuluan.

\section{Penyiapan Hewan Uji}


Larva udang Artemia Salina L ditetaskan dengan merendam telurdalam aquarium yang berisi air laut dan diberi aerator, 24 jam sebelum dilakukan uji. Bagian air laut yang tidak berisi telur diberi penerangan. Hal ini bertujuan agar larva yang sudah menetas bergerak menuju cahaya, sehingga terpisah dari cangkang telurnya.

\section{Pengujian Bioaktivitas}

Pelaksanaan uji dilakukan dengan memasukkan 10 ekor larva berumur 48 jam ke dalam vial berisi larutan uji ekstrak dan fraksi n-heksanan daun sungkai. Tiap kelompok perlakuan dilakukan replikasi lima kali. Volume akhir tiap-tiap vial sebesar $5 \mathrm{ml}$. Vial kemudian diletakkan dibawah penerangan selama 24 jam, kemudian dihitung jumlah larva yang mati.

\section{HASIL DAN PEMBAHASAN}

Pada penelitian ini dilakukan penghitungan rendemen, pengujian bioaktivitas ekstrak methanol dan nheksana daun Sungkai terhadap Artemia salina Leach dengan menggunakan metode Brine Shrimp Lethality Test (BSLT). Brine Shrimp Lethality Test (BSLT) adalah salah satu metode skrining untuk menentukan bioaktivitas suatu senyawa atau ekstrak secara akut dengan menggunakan hewan uji Artemia salina Leach.Ekstrak yang diperoleh, kemudian diujikan ke bioindikator untuk mengetahui bioaktivitas dari masingmasing ekstrak. Daya bioaktivitas suatu ekstark dapat diketahui dengan perhitungan jumlah kematian larva udang dengan parameter Lethal
Concentration $50 \quad\left(\mathrm{LC}_{50}\right) . \quad$ Ekstrak bersifat toksik bila harga $\mathrm{LC}_{50}<1000$ ppm, Ekstrak atau fraksi senyawa yang memiliki nilai $\mathrm{LC}_{50}<30 \mathrm{ppm}$ berpotensi sebagai sitotoksik, LC L $_{50}$ 30-200 ppm berpotensi sebagai antimikroba, sedangkan $\mathrm{LC}_{50} \quad$ 200-1000 ppm berpotensi sebagai pestisida (Fathiyawati, 2008).

\section{Rendemen Ekstrak dan Fraksi Daun Sungkai}

Sampel daun sungkai yang digunakan adalah 2370 gram. Lalu dilakukan pengeringan pada daun sungkai dengan tujuan mendapatkan simplisia daun sungkai yang tidak mudah rusak sehingga dapat disimpan dalam waktu lama. Berat sampel kering yang diperoleh adalah 586 gram. Setelah itu dilakukan perajangan untuk memperluas bidang kontak antara cairan pelarut dengan simplisia.

Sampel kering kemudian dimaserasi dengan pelarut metanol. Maserasi dilakukan dengan cara merendam simplisia dalam cairan penyari. Kemudian dilakukan penguapan dengan rotary evaporator sehingga didapatkan ekstrak metanol sebanyak 80,223 gram.

Berdasarkan tabel 1, rendemen ekstrak kasar terhadap sampel segar sebesar $3,38 \%$ dan terhadap sampel kering sebesar13,79\%, hasil dari fraksinasi menggunakan pelarut $n$ heksana adalah 3,64\%. Dari hasil tersebut menunjukkan sifat senyawa yang dominan terdapat pada daun Sungkai bersifat non polar.

Tabel 1 Data Rendamen Ekstrak Daun Sumgkai

\begin{tabular}{ccccc}
\hline \multirow{2}{*}{ No. } & Ekstrak Daun Sungkai & \multicolumn{3}{c}{ Rendemen Ekstrak Batang Grinsat (\%) } \\
\cline { 3 - 5 } & & Sampel Segar & Sampel Kering & Ekstrak Metanol \\
& $2370 \mathrm{~g}$ & $586 \mathrm{~g}$ & $80,223 \mathrm{~g}$ \\
\hline 1. & Ekstrak Kasar & $3,38 \%$ & $13,79 \%$ & - \\
2. & Fraksi $n$-heksana & $0,12 \%$ & $0,49 \%$ & $3,64 \%$ \\
\hline
\end{tabular}


Bioaktivitas Ekstrak Metanol Daun Sungkai

Bioaktivitas ekstrak daun Sungkai dapat dihitung dengan menggunakan hasil pengujian yang diperoleh setelah diinkubasi selama 24 jam.

Hasil pengujian (Tabel 2) menunjukkan bahwa terjadi kematian $50 \%$ hewan uji pada konsentrasi antara $200-400 \mu \mathrm{g} / \mathrm{mL}$. Hasil uji ini membuktikan bahwa ekstrak metanol daun Sungkai membunuh 50\% hewan uji Artemia salina Leach. Grafik akumulasi hewan uji yang mati dan akumulasi hewan uji yang hidup dapat dilihat pada Gambar 1.
Terlihat pada Gambar 1 peningkatan konsentrasi ekstrak metanol daun Sungkai dalam kemampuan membunuh hewan uji larva udang Artemia Salina, yaitu dengan bertambahnya larva udang yang mati. Ini terlihat dari hasil analisis dengan metode Reed and Muench dengan nilai $\mathrm{LC}_{50}$ $387,257 \mu \mathrm{g} / \mathrm{mL}$. Hasil perhitungan batas kepercayaan angka $\mathrm{LC}_{50}$ berada antara batasan $238,781 \mu \mathrm{g} / \mathrm{mL}-628,058 \mu \mathrm{g} / \mathrm{mL}$ dengan ukuran kesalahan sebesar 0,105. Berdasarkan nilai LC $_{50}$ ekstrak metanol daun Sungkai menunjukkan bahwa ekstrak metanol daun Sungkai berpotensi pestisida alami $\left(\mathrm{LC}_{50} 200-400 \mu \mathrm{g} / \mathrm{mL}\right)$.

Tabel 2 Hasil Uji Ekstrak Metanol Terhadap Larva Udang Artemia salina Leach

\begin{tabular}{|c|c|c|c|c|c|c|c|}
\hline \multirow{2}{*}{$\begin{array}{c}\text { Konsentrasi } \\
(\mathrm{ppm})\end{array}$} & Log & \multicolumn{2}{|c|}{ Jumlah } & \multicolumn{2}{c|}{ Terakumulasi } & $\begin{array}{c}\text { Rasio mati: } \\
\text { total }\end{array}$ & $\begin{array}{c}\text { Mortalitas } \\
(\%)\end{array}$ \\
\cline { 3 - 8 } & Konsentasi & Mati & Hidup & $\begin{array}{c}\text { Mati } \\
(\mathrm{x})\end{array}$ & $\begin{array}{c}\text { Hidup } \\
(\mathrm{y})\end{array}$ & $\begin{array}{c}\text { Terakumulasi } \\
\mathrm{x}:(\mathrm{x}+\mathrm{y})\end{array}$ & $\begin{array}{c}\text { Rasio x } \\
100\end{array}$ \\
\hline 50 & 1,699 & 9 & 41 & 9 & 121 & 0,06 & 6 \\
\hline 200 & 2,301 & 24 & 26 & 33 & 80 & 0,29 & 29 \\
\hline 400 & 2,602 & 25 & 25 & 58 & 54 & 0,51 & 51 \\
\hline 800 & 2,903 & 26 & 24 & 84 & 29 & 0,74 & 74 \\
\hline 1000 & 3 & 45 & 5 & 129 & 5 & 0,96 & 96 \\
\hline
\end{tabular}

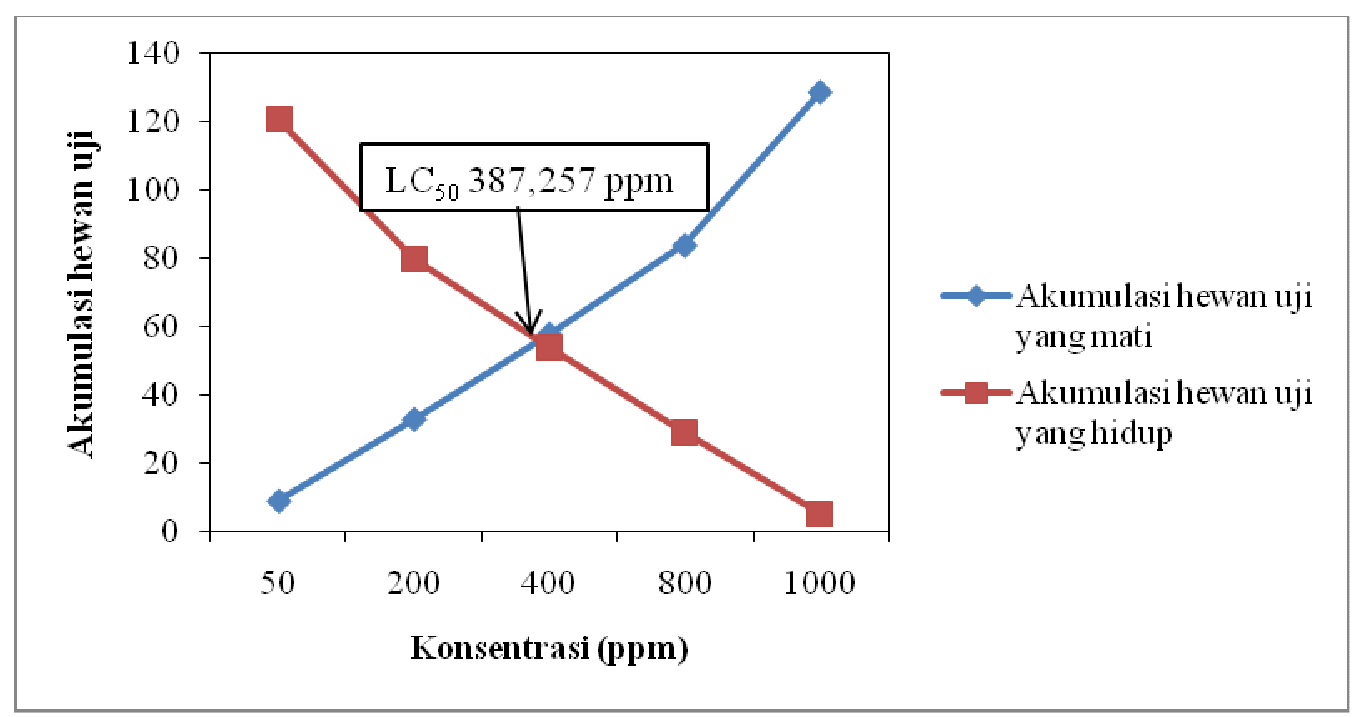

Gambar 1. LC $_{50}$ ekstrak metanol Daun Sungkai 
Tabel 3 Hasil Uji Fraksi n-heksana Terhadap Larva Udang Artemia salina Leach

\begin{tabular}{|c|c|c|c|c|c|c|c|}
\hline \multirow{2}{*}{ Konsentrasi } & \multirow{2}{*}{$\begin{array}{c}\text { Log } \\
\text { Konsentrasi }\end{array}$} & \multicolumn{2}{|c|}{ JumLah } & \multicolumn{2}{|c|}{ Terakumulasi } & $\begin{array}{c}\text { Rasio mati: } \\
\text { total }\end{array}$ & $\begin{array}{c}\text { Mortalitas } \\
(\%)\end{array}$ \\
\cline { 3 - 8 } & & Mati & Hidup & $\begin{array}{c}\text { Mati } \\
(\mathrm{x})\end{array}$ & $\begin{array}{c}\text { Hidup } \\
(\mathrm{y})\end{array}$ & $\begin{array}{c}\text { Terakumulasi } \\
\mathrm{x}:(\mathrm{x}+\mathrm{y})\end{array}$ & $\begin{array}{c}\text { Rasio } \mathrm{x} \\
100\end{array}$ \\
\hline $10 \mathrm{ppm}$ & 1 & 13 & 37 & 13 & 125 & 0,09 & 9 \\
\hline $50 \mathrm{ppm}$ & 1.699 & 16 & 34 & 29 & 88 & 0,24 & 24 \\
\hline $100 \mathrm{ppm}$ & 2 & 20 & 30 & 49 & 54 & 0,47 & 47 \\
\hline $200 \mathrm{ppm}$ & 2,301 & 31 & 19 & 80 & 24 & 0,76 & 76 \\
\hline $400 \mathrm{ppm}$ & 2,602 & 45 & 5 & 125 & 5 & 0,96 & 96 \\
\hline
\end{tabular}

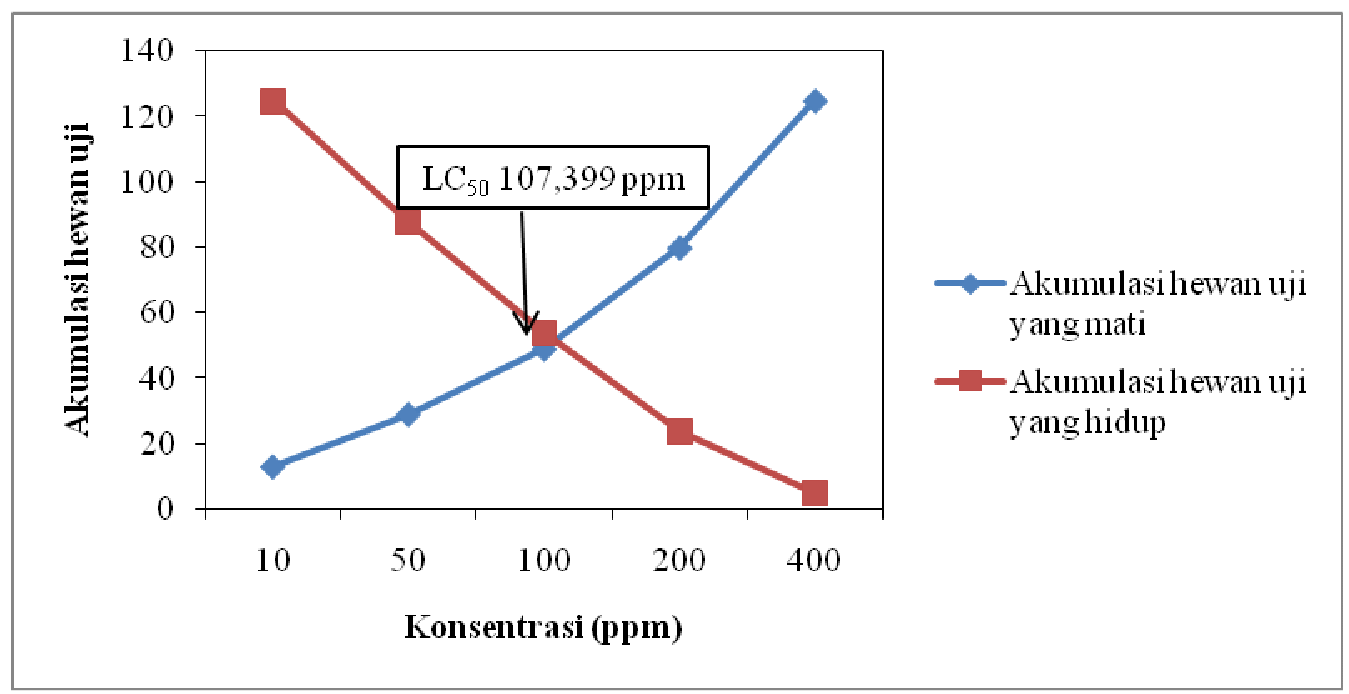

Gambar 2. LC 50 Fraksi n-Heksana daun Sungkai

Bioaktivitas Fraksi n-Heksana Daun Sungkai

Bioaktivitas fraksi n-heksana daun Sungkai dapat dihitung dengan menggunakan hasil pengujian yang diperoleh setelah diinkubasi selama 24 jam.

Hasil pengujian (Tabel 3) menunjukkan bahwa terjadi kematian $50 \%$ hewan uji pada konsentrasi antara $100-200 \mu \mathrm{g} / \mathrm{mL}$. Hasil uji ini membuktikan bahwa fraksi n-heksana daun Sungkai mampu membunuh 50\% hewan uji Artemia salina Leach. Grafik akumulasi hewan uji yang mati dan akumulasi hewan uji yang hidup dapat dilihat pada Gambar 2.

Terlihat pada Gambar 2 peningkatan konsentrasi fraksi n-heksana daun Sungkai dalam kemampuan membunuh hewan uji larva udang, yaitu dengan bertambahnya larva udang yang mati. Ini terlihat dari hasil analisis dengan metode Reed and Muench dengan nilai $\mathrm{LC}_{50} 107,399 \mu \mathrm{g} / \mathrm{mL}$. Hasil perhitungan batas kepercayaan angka $\mathrm{LC}_{50}$ berada antara batasan 26,977 $\mu \mathrm{g} / \mathrm{mL}-427,563 \mu \mathrm{g} / \mathrm{mL}$ dengan ukuran kesalahan sebesar 0,030. Berdasarkan nilai $\mathrm{LC}_{50}$ fraksi n-heksana daun Sungkai menunjukkan bahwa fraksi n-heksana daun Sungkai berpotensi antimikroba ( LC $_{50} 30-200 \mu \mathrm{g} / \mathrm{mL}$ ).

\section{Hubungan Bioaktivitas Dengan Kandungan Metabolit Sekunder}

Kandungan metabolit sekunder yang terdapat dalam tumbuhan berhubungan dengan aktivitas biologis suatu tumbuhan. dengan teridentifikasinya metabolit sekunder yang terdapat pada daun Sungkai, 
menandakan bahwa daun Sungkai memiliki potensi sebagai bahan obat alami dan dapat memberikan gambaran kandungan metabolit sekunder apa saja yang memberikan aktivitas terhadap bioindikator uji.

Bioaktivitas daun Sungkai pada ekstrak metanol dan berbagai fraksi berbeda-beda, kemungkinan ini disebabkan oleh kandungan metabolit sekunder tiap ekstrak yang berbeda sehingga terdapat ekstrak yang memberikan aktivitas lemah dan ada yang memberikan aktivitas yang kuat terhadap bioindikator. Parameter bioaktivitas yaitu nilai LC50. LC50 merupakan konsentrasi ekstrak yang dimana hewan uji diberikan ekstrak dan menyebabkan kematian pada 50\% hewan coba. Dalam penelitian ini, LC50 ekstrak daun Sungkai adalah konsentrasi ekstrak daun Sungkai tunggal didalam air laut pada setiap tabung/ uji yang menyebabkan kematian pada 50\% larva Artemia salina Leach. Berdasarkan metode BSLT, suatu ekstrak dikatakan aktif jika harga LC50 $1000 \mu \mathrm{g} / \mathrm{mL}$. Semakin kecil dari $1000 \mu \mathrm{g} / \mathrm{mL}$, ekstrak semakin bersifat sitotoksik.Nilai LC50 ekstrak metanol $387,257 \mu \mathrm{g} / \mathrm{mL}$, hasil tersebut membuktikan bahwa konsentrasi daun Sungkai berpotensi sebagai pestisida alami (LC50 200-400 $\mu \mathrm{g} / \mathrm{mL}$ ). Nilai LC50 fraksi n-heksana 107,399 $\mu \mathrm{g} / \mathrm{mL}$, hasil tersebut membuktikan bahwa konsentrasi daun Sungkai memiliki potensi sebagai antimikroba (LC50 100-200 $\mu \mathrm{g} / \mathrm{mL}$ ).

Mekanisme kematian larva Artemia salina Leach diperkirakan berhubungan dengan fungsi golongan senyawa metabolit sekunder yaitu alkaloid, saponin, senyawa fenol, steroid dan terpenoid, serta tanin dalam daun Sungkai yang dapat menghambat daya makan larva (antifeedant). Cara kerja senyawa tersebut adalah dengan bertindak sebagai stomach poisoning atau racun perut. Kemungkinan senyawa tersebut masuk ke dalam tubuh larva, sehingga alat pencernaannya akan terganggu. Senyawa ini juga dapat menghambat reseptor perasa pada daerah mulut larva. Hal ini mengakibatkan larva tidak mampu mengenali makanannya.

\section{KESIMPULAN}

1. Persentase rendemen ekstrak kasar terhadap sampel segar sebesar 3,38\% dan terhadap sampel kering sebesar $13,79 \%$.

2. Bioaktivitas ekstrak methanol Daun Sungkai (Peronema canescens Jack) terhadap larva udang berdasarkan nilai $\mathrm{LC}_{50}$ adalah $387,257 \mu \mathrm{g} / \mathrm{mL}$, sedangakan pada fraksi n-heksana peroleh nilai $\mathrm{LC}_{50}$ adalah 107,399 $\mu \mathrm{g} / \mathrm{mL}$.

\section{UCAPAN TERIMA KASIH}

Disampaikan pada Rosyid Hidayat atas keterlibatannya dalam penelitian ini. Kepala Laboratorium Penelitian dan Pengembangan Farmaka Tropis atas izin dan fasilitas yang diberikan selama penelitian.

\section{DAFTAR PUSTAKA}

1. Francisconi, M.D.S. 2012. Artemia salina Leach. Diakses 15 Juli 2012. (http://www.bib.unesc.net)

2. Colegate,. 1993. Bioactive Natural Products: Detection, Isolation, and Structural Determination. CRC Press Inc: Florida.

3. Gunawan, Didik, dan Sri Mulyani. 2004. Ilmu Obat Alam(Farmakognosi) Jilid 1. Penebar Swadaya. Jakarta

4. Hadi, I. 2011. Identifikasi Metabolit Sekunder dan Aktivitas Antibakteri Ekstrak Daun Sungkai (Peronema canescens Jack). Skripsi Fakultas Farmasi Universitas Mulawarman Samarinda. Samarinda. 